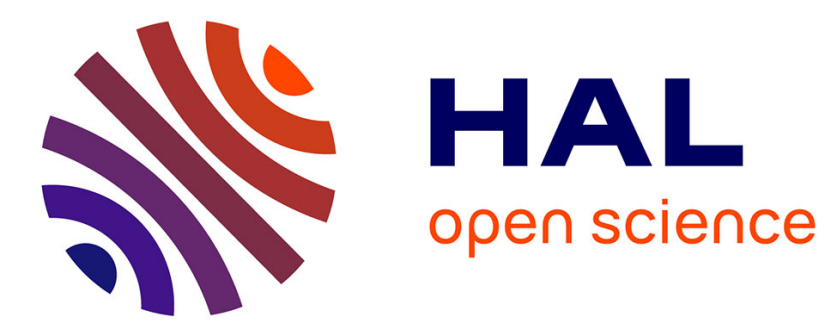

\title{
Mapping the Distortions in Time and Space: The French Railway Network 1830-1930
}

Thomas Thévenin, Robert Schwartz, Loïc Sapet

\section{To cite this version:}

Thomas Thévenin, Robert Schwartz, Loïc Sapet. Mapping the Distortions in Time and Space: The French Railway Network 1830-1930. Historical Methods: A Journal of Quantitative and Interdisciplinary History, 2013, 46 (3), pp.134-143. 10.1080/01615440.2013.803409 . hal-00911034

\section{HAL Id: hal-00911034 \\ https://hal.science/hal-00911034}

Submitted on 22 Jul 2019

HAL is a multi-disciplinary open access archive for the deposit and dissemination of scientific research documents, whether they are published or not. The documents may come from teaching and research institutions in France or abroad, or from public or private research centers.
L'archive ouverte pluridisciplinaire HAL, est destinée au dépôt et à la diffusion de documents scientifiques de niveau recherche, publiés ou non, émanant des établissements d'enseignement et de recherche français ou étrangers, des laboratoires publics ou privés. 


\title{
Mapping the Distortions in Time and Space
}

\author{
The French Railway Network, 1830-1930
}

\author{
THOMAS THÉVENIN \\ Department of Geography, UMR ThéMA \\ Universite de Bourgogne \\ ROBERT SCHWARTZ \\ Department of History \\ Mount Holyoke College \\ LOÏC SAPET \\ Department of Geography, UMR ThéMA \\ Universite de Bourgogne
}

\begin{abstract}
Accessibility is frequently used in transportation planning to measure the efficiency of new infrastructure in terms of travel time and population served. In this article, the authors apply accessibility concepts based on the geo-historical angle. The aim of this study is to investigate the relationships between population dynamics and the railway expansion from 1830 to 1930 . Their approach considers a local scale composed of some 36,000 French communes for the demographic data and more than 28,000 kilometers for the railway network. The methodological framework of this database is based on historical geographic information systems completed by anamorphosis analysis. In this way, they are able to map the changing contours of accessibility from the local to the regional and national scales for historical time.
\end{abstract}

Keywords: accessibility, anamorphosis, H-GIS, spatial analysis, transportation

I $\mathrm{n}$ the early twentieth century, the French geographer Paul Vidal de la Blache characterized the growth of the railway networks as a true upheaval of human history (Vidal de la Blache 1903). The "invention of speed" (Studeny 1995) drastically reduced travel time and consequently altered humans' space-time perceptions. As a striking example, in 1814 traveling from Paris to Marseille took four to five days; by

Partial funding was provided by the EU (Jean Monnet 200215-LLP2011-ES-AJM-IC).

Address correspondence to Thomas Thévenin, Department of Geography, Universite de Bourgogne, 2 Boulevard Gabriel, 21000 Dijon, France. E-mail: thomas.thevenin@u-bourgogne.fr
1857, it took about 13 hours. More recently, the railway revolution has been studied using a geo-historical approach (Knowles 2005; Bretagnolle and Verdier 2007; Gregory and Ell 2007; Boonstra 2009; Gregory, Marti-Henneberg, and Tapiador 2010). Furthermore, the historical geographical information system (H-GIS) is playing a central role in assembling historical material on transportation and analyzing the interrelationships between rail networks and geographical space. In the effort, the concept and measurement of accessibility is of central importance. In what follows, we offer an improved method for estimating accessibility so that the impacts of the French railway network revolution between 1830 and 1930 can be better understood.

Accessibility measures, frequently used in urban and transportation planning, are used to determine the impacts of new infrastructures upon transportation services. The effect of "high speed" trains, particularly in urban European areas, has been studied from the perspective of travel-time required (Chapelon and Leclerc 2007). Our approach is similar but uses geo-historical methods. As described by Walter Hansen (Hansen 1959), all studies of accessibility have emphasized that the concept is fraught with difficulties, and many disciplines have offered various definitions of it. In transport geography, Mei Po Kwan and colleagues (2005) defined accessibility as incorporating both the potential advantages and the effort required to travel through space to reach a single place, resource, or community amenity. Karts Geurs and Ritsema van Eck (2001) extended the concept to mean the efficiency 
of conveying individuals or goods to a destination using one or more modes of transport. Our geo-historical approach integrates those definitions by employing graph theory.

Our historical research began by collecting information from archival and printed sources. Then the extracted information was entered into a GIS database, and with that data we calculated accessibility in France across national space and historical time. Finally, with the aid of anamorphosis maps, we produced displays of relative accessibility, as measured by travel times, between given points in the country. ${ }^{1}$

\section{An H-GIS Dedicated to Transportation Research}

With regard to accessibility, the work of D. Marble (Goodchild 2000) in the late 1950s foreshadowed the development during the 1990s of GIS (Thill 2000) for transportation research. The requisite tools were created collaboratively through correspondence and important annual conferences held in the United States. Then during the early 2000s, the GIS methods originally devoted to contemporary planning of transportation networks were applied to historical questions and research. The three examples below illustrate how various projects have developed the use of historical GIS.

\section{Three Examples of H-GIS Projects: The United States, Great Britain, and Europe}

A research project entitled "Railroads and the Making of Modern America," directed by W. G. Thomas, was designed to show that during the period 1850-1900 the U.S. railway network modified social, economic, and political relationships and helped develop a national identity among the individual states. In that H-GIS, the researchers compiled both historical information and data on the spatial characteristics of the rail lines, giving a highest priority on incorporating a broad wealth of data, as opposed to their precise accuracy. Their results provided new understandings of diverse issues such as the strikes of 1877, patterns of migration, and the evolution of mass tourism.

About that same time, Ian Gregory and Robert Schwartz were incorporating demographic data from the Great Britain H-GIS into their research project on the expansion of the railway system in Great Britain during the nineteenth and early twentieth centuries (Gregory and Schwartz 2009). The period of study began in 1840, 15 years after Great Britain inaugurated the first successful steam-powered railway line in the world. The GIS included censual demographic data at three different geographic scales: English and Welsh counties, census registration districts, and parishes. As in France, many of these units' administrative boundaries shifted over the years, so a means must be devised to integrate into the GIS the different boundaries of different dates to avoid the modifiable areal unit problem (MAUP).

At the district level, the inter-censual population totals joined with mortality rates by age and sex groups made it possible to estimate levels of net migration by the groups. The data on the railway network itself was derived from Colonel Michael Cobb's atlas, The Railways of Great Britain (2006). In all, 31,000 km of railway lines were digitized with the help of Spanish geographers (Gregory et al. 2010).

As an outgrowth of that project, this team went on to develop a much larger H-GIS that covered Europe's rail transportation networks from 1825 to the present (MartiHenneberg 2012). The vast project, including nine countries and partially funded by the European Science Foundation, was designed to study relationships between the rail transport system and economic and demographic change.

In our project on French railways of the nineteenth and early twentieth centuries, we must meet four challenges:

- designing spatial analytic tools to identify spatial and temporal patterns of change,

- defining attributes that linked dates and locations,

- applying spatial modeling to historical data, and

- creating geo-visualizations and animated maps to help demonstrate the results of the study.

In addressing these challenges, H-GIS has proved a very useful means of integrating geography and history.

\section{France: From Historical Sources to the H-GIS Database}

In the data-collection phase (Figure 1), we digitized railway maps produced by the French National Railway Company (SNCF) in the 1940s. Our digitized images were then geo-referenced, using as base maps the current railway network in the Road 500 database created by the French geographic agency, IGN. To complement the SNCF maps and the Cima database for main rail lines, we collected information on secondary lines from other sources, including the geography of the lines and their opening and closing dates (Domengie 1985, 1986; Domengie and Banaudo 1990, 1995a, 1995b). Currently, our database contains $56,000 \mathrm{~km}$ of railway lines and 11,000 stations covering the period 1827-2001. In addition to opening and closing dates, we added data on other characteristics of the line (e.g., doubletrack, single-track), locomotive power (steam or electricity), and the names of the private rail companies that operated each line. Then, as in the Great Britain project, we integrated French demographic data at the level of the commune, the smallest unit of French administration (Motte, Séguy, and Théré 2003).

To measure the accessibility of these rail lines from 1827 to 2001, we collected information on the evolving speed of trains on the main rail lines, using two main sources: the companies' timetables and recorded train speeds in each period studied, similar to what was done for a 2005 article on British railways (Crafts and Leunig 2008). The British data on the hours of daily departures and arrivals came from the digitalized Bradshaw timetables but comprised information on only 50 rail lines. Our project incorporates accessibility 


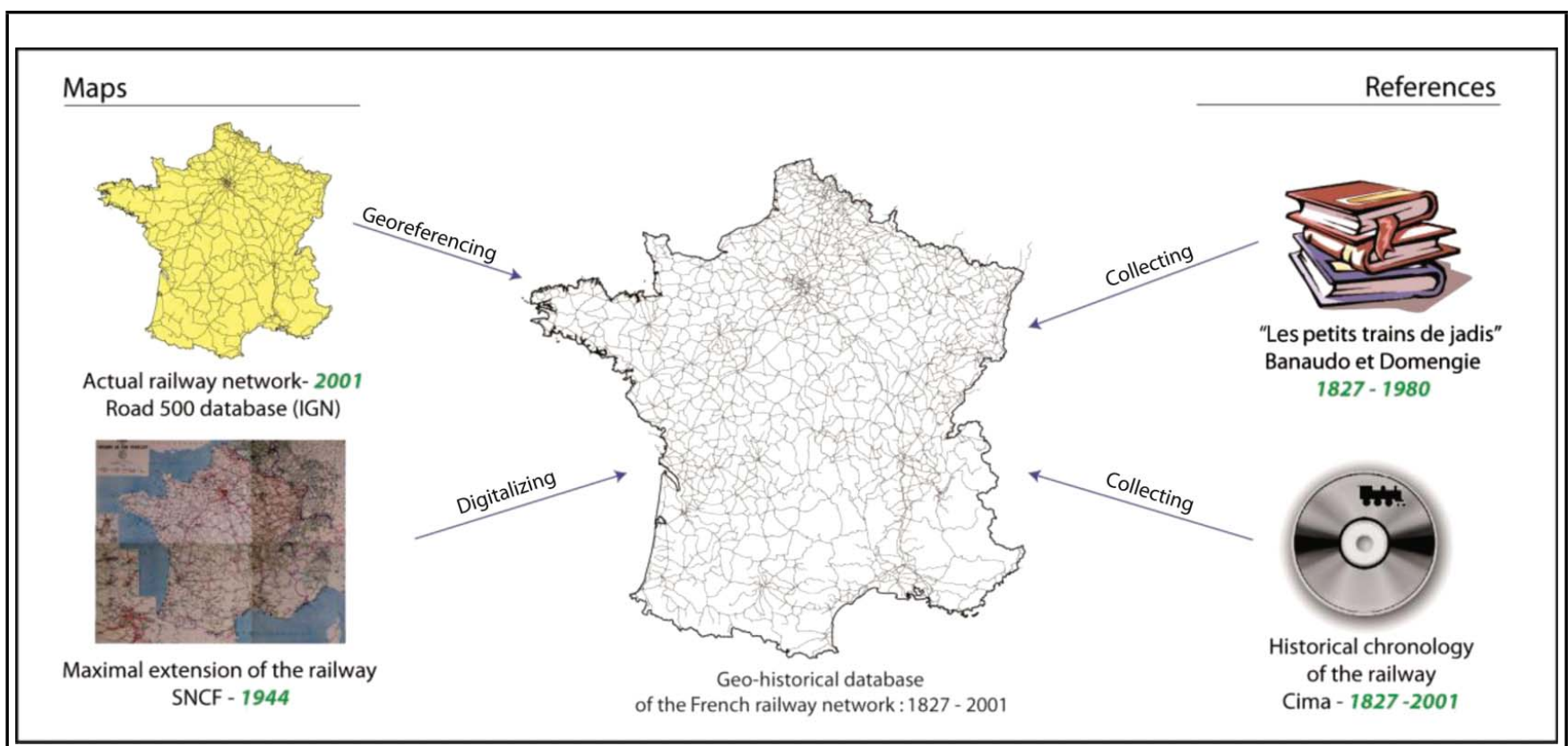

FIGURE 1. Characterization and digitalization of the railway network 1827-2001 (color figure available).

measures for all of France's railways. To devise estimates of French train speeds, we drew on secondary studies about network growth (Studeny 1995; Caron 1997), electrification (Blier 1991; Bretagnolle 2003), and technical advances in train design. Travel times and speeds were then adjusted to the topographical constraints and infrastructure quality of each line (Figure 2). This work allowed us to calculate and graph the mean speeds on the different types of rail lines at different time periods for the entire national network.

\section{Evolution of the French Railways From 1840 to 1930}

The network growth and speeds shown on the maps (Figure 3) cover three main eras of French railway expansion. The

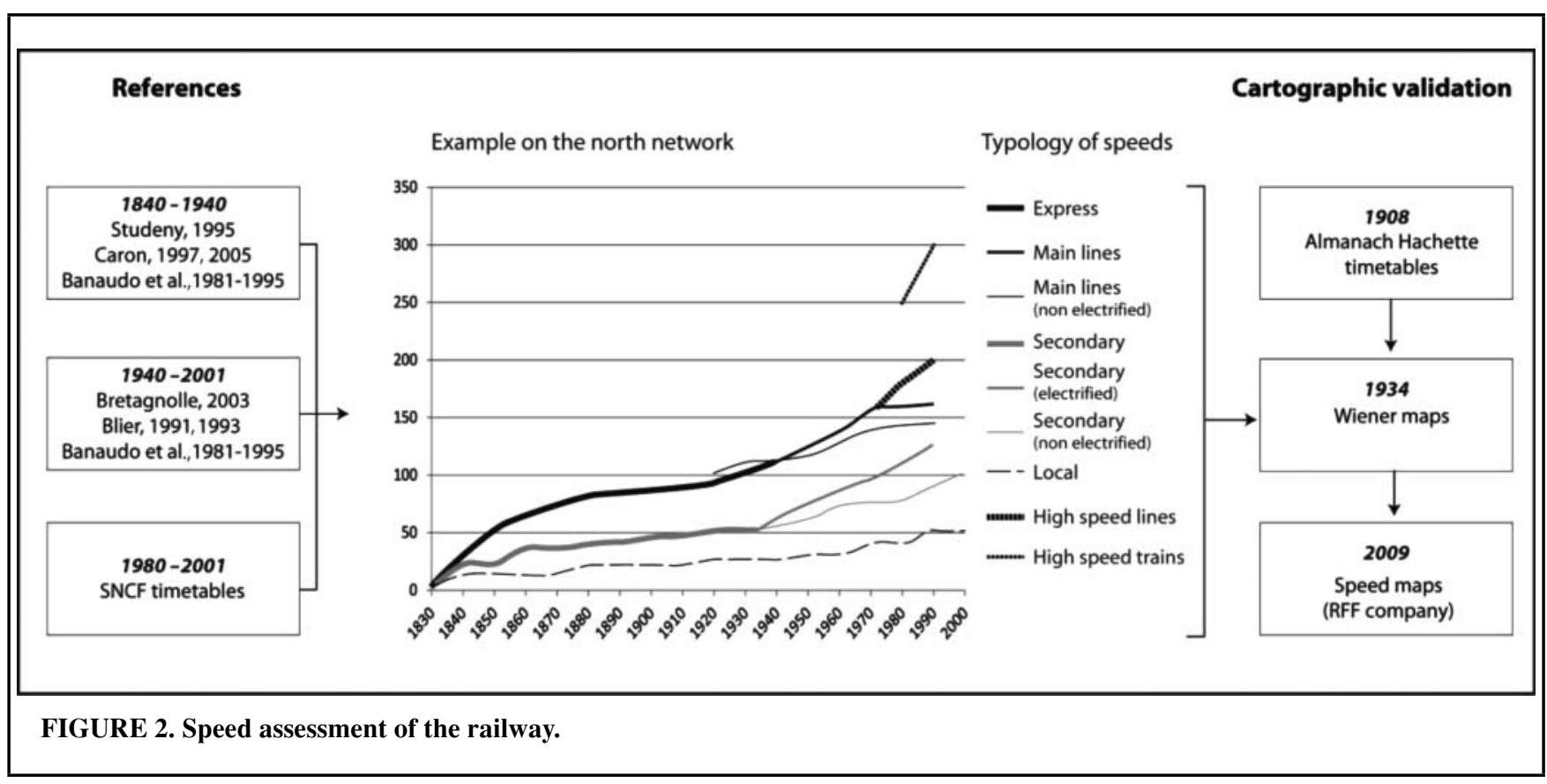




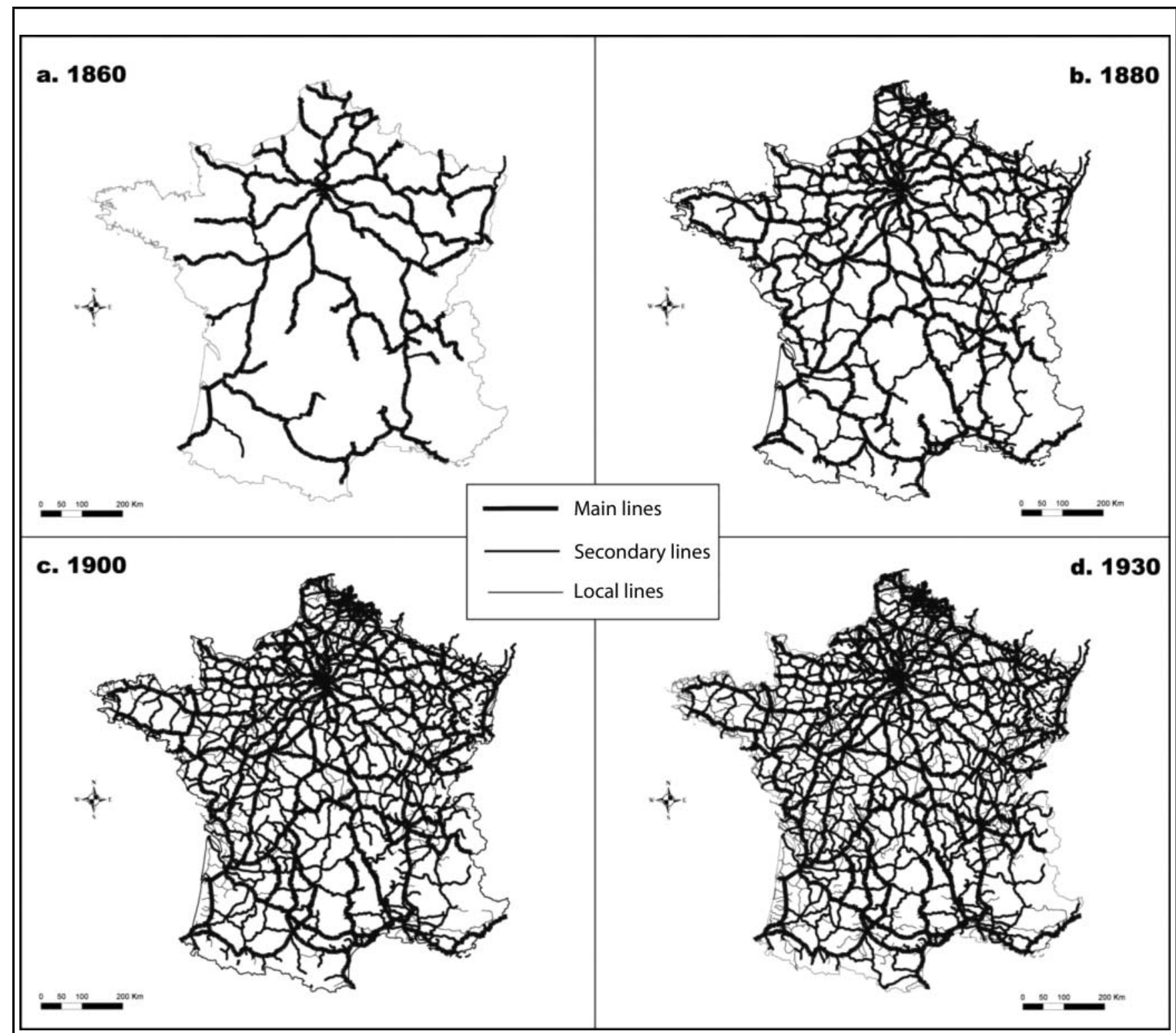

FIGURE 3. The French railway network growth.

first phase from 1840 to 1860 established the French rail network's shape and hierarchy, largely reflecting the converging political and economic interests at the national level. Following the so-called Legrand plan, rail lines served as spokes radiating out from the hub at Paris. This geography reflected the two primary objectives: the French government's effort to link major cities, borders, and coastlines to the capital of Paris; and its desire to facilitate the growth of major French rail companies in the various other areas of France. By the early nineteenth century, if not earlier, striking economic disparities existed between the developing French North versus the less developed South, and the more extensive growth of railways in the North reflected the heavier industrial de- velopment and population density there, at the expense of the South.

The second phase of railway extension occurred between 1860 and 1900, and by the turn of the century France's surging construction had generated $45,000 \mathrm{~km}$ of rail lines, main lines, and newer secondary included. As announced in the Migneret law of 1865 , the purpose of secondary networks was to provide direct connections among all departmental seats (prefectures). Train speeds on secondary lines were slower than those on main lines, resulting in an increase in additional spatial disparities between the favored areas around Paris and Lille in the North and those elsewhere. 
A final phase of rail expansion lasted from the end of nineteenth century to about 1930 . By its close, $56,000 \mathrm{~km}$ of railway lines were active. This maximal extension of the network realized the Freycinet plan of expansion introduced in 1878 . From then until 1914, some $18,000 \mathrm{~km}$ of new track was laid. Most were comparatively short and of low speed, railways designated "lines of local interest." Although a higher density of rail service persisted in the North and Easterly parts of France, service to the Southern and mountainous regions expanded, reducing the disparities that were so marked by 1860.

\section{Measuring "Bi-Modal" Accessibility}

Defining and measuring accessibility yields a good idea of how well the rail network served the population at different dates and in different regions. Since rail lines in a metropolitan area did not serve all areas equally, we developed a twophase accessibility measure by summing the times (in hours) of pedestrian travel to the nearest station and train travel from there to Paris or any give commune. The hours were calculated at points 10 years apart and them compared.

\section{A Pedestrian-Accessibility Measurement}

To gauge accessibility, we must take into account how people actually reached the nearest railway transportation. In the earliest period under study, the principal means of reaching a train station was on foot or else traveling on some type of horse-drawn vehicle. We classified both modes as pedestrian forms of travel and included the practical realities of that mode in considering railway accessibility from 1860 to 1930 . The measurement seemed to entail two factors affecting pedestrians traversing geographical space:

- heterogeneity (i.e., that human habitations were dispersed irregularly in different places), and

- anisotropy (i.e., that the pace of local travel varied depending on the topography traversed).

To account for such factors, we integrated locations of all the communes into a digital elevation model so we could derive a rough estimate of how the local settlement pattern and topography would impact rail accessibility for the commune. From those estimates, for each decade of our study we calculated an average distance that a pedestrian must travel from the commune to the closest railway station. Then, using $5 \mathrm{~km} / \mathrm{hr}$ as an average walking speed and varying it per the route's terrain (i.e., decreasing pedestrian speed on an uphill route or increasing it on a downward route), we generated a local estimate of pedestrian pace for use in calculating the commune's rail accessibility in the nineteenth century.

Our best estimates suggest that in 1850, an inhabitant of a typical commune would pass at least 24 hours en route to the nearest rail station. By the turn of the twentieth century, almost all French communes (i.e., except for those in mountainous regions) had fairly good access to the national railway network; in fact, by then there was a station within $10-15 \mathrm{~km}$ (as the crow flies) of a great majority of communes (Schwartz, Gregory, and Thévenin 2011). In short, the average French citizen in the 1860s must count on three days to reach the nearest railway station, whereas by 1900 he could reach a train station and be heading by train to Paris in less than three hours.

\section{Accessibility to Paris and Population Served}

Temporal disparities in rail service between any given commune and Paris indicate clearly that not all rail links were equally convenient or accessible. Reducing such disparities requires a fully-interconnected network, a status not achieved until 1860, so it seems appropriate to begin our analysis of national rail accessibility that year. Similarly, a natural endpoint for the study seemed to be 1930, a year when, with the future dominance of the automobile evident, France began closing down local lines. Extending beyond 1930 would require taking into account car and/or bus transport in order to calculate the functional access to stations, a project clearly too complex for us to pursue at this point. Thus, we modeled and estimated the accessibility to the French railway system only for the period between 1860 and 1930 and referenced the time needed to walk to the nearest station and then reach the chosen destination by rail.

For this analysis, we assumed that once aboard the railway, actual travel speeds would vary depending on which category of rail line was involved: main, secondary, or local. We assigned a mean speed for each type of line, also reflecting its respective route. A bi-modal accessibility measure is derived from two specific calculations. One, the time-distance, was determined for every [nearest-neighbor] pair of commune/station, using the following formula:

$$
\begin{aligned}
& A_{(C, G o)}=\min [e(C, S o)] \\
& \text { C: Commune }
\end{aligned}
$$

\section{So: Station of origin}

A second calculation sums up estimated travel times from station-to-station, all along the travel route, using the mean rates of speed appropriate to the main, secondary, or local lines involved in reaching Paris, our specified final destination. Combining the two values yielded a measure of a unipolar accessibility (UA): the travel time for a one-way trip from any of 36,565 French communes to the closest railway station within Paris:

$$
\begin{aligned}
& U A_{(C, S p)}=\min [e(C, S o)]+\min [e(C, S p)] \\
& \text { C: Commune }
\end{aligned}
$$

So: Station of origin

Sp: Station of Paris 


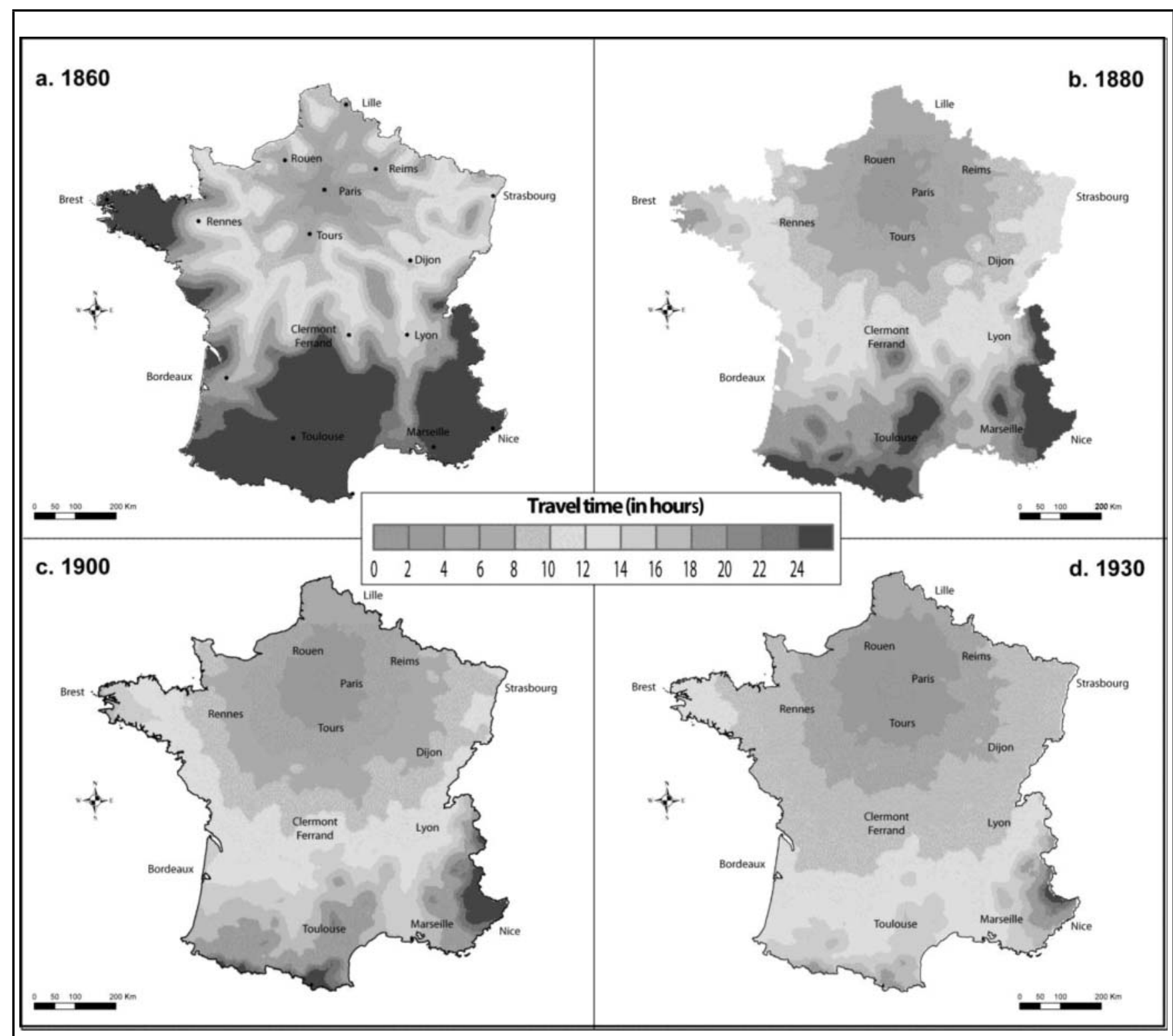

FIGURE 4. Evolution of accessibility to Paris.

Frequently used in transportation geography, estimates of UA can best be visualized and studied via an isochronic map that displays the spatially smoothed values of (potential) accessibility. In each map in Figure 4, zones of good accessibility (i.e., those with a travel time to Paris of under eight hours) are represented in graduated shades of green. On the opposite end of the scale, poor accessibility zones, requiring over 20 hours to reach Paris, are indicated in graduated shades of red. Intermediate zones are coded in shades of light green and orange. Comparing the maps (Figure 4) that correspond to a different period reveals striking patterns of historical change in accessibility. A line scribed from Bordeaux to Lyon serves as a rough boundary separating Northern and Southern France and shows that great disparities in accessi- bility between those two regions persisted until at least 1880 . By 1900 , travelers heading to Paris from South of the line faced a journey of 12-14 hours, a very long haul compared to their counterparts' trip from Northeast France. Nevertheless, the maps show that over time the big disparities in accessibility between the North and South diminished significantly and even more markedly once the Freycinet program of 1878 actually got underway in the 1890s.

\section{Revealing Space-Time Distortions}

The advent of new modes of transportation profoundly changed the relationships of different segments of the French 


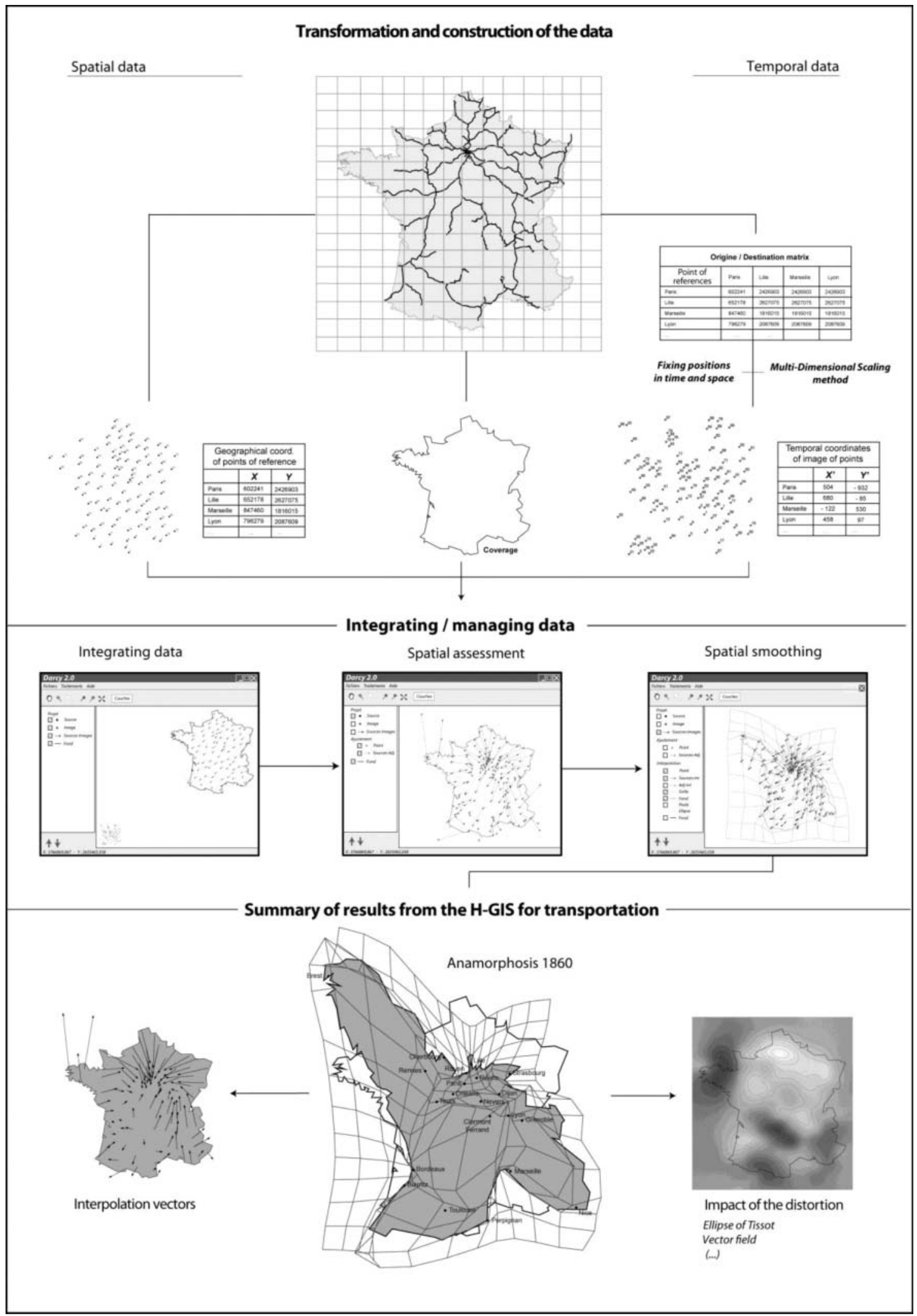

FIGURE 5. A methodology for geo-historical anamorphosis. 
population to space and time. New cartographic representations, like temporal metric maps, take into account the perception of inaccessible, as opposed to accessible, spaces. Anamorphosis representations, suggested by Constantin Pecquer in 1839 , prove to be a trail-blazer technique in this field.

\section{Cartographic Distortion Process: History, Principles, and Method}

This process consists of allowing a classic boundary shape on a map to distort depending on specific attributes. Based on the work of Wentworth d'Arcy Thompson (1948) and later by Stephen Jay Gould (1971), this method was popularized through the work of Colette Cauvin in the 1980's. Applied to travel time, we use multipolar anamorphosis in order to accentuate the accessibility contrasts between different points in study space.

The method is organized in three main steps (Figure 5). First, we calculate the origin-and-destination matrix for a sample of 100 homogeneous points. We link this information to a first layer of initial points and a second "image layer" of points based on the temporal coordinates. A last layer is used to determine the boundaries of the reference area.

In a second phase, we apply a spatial adjustment in order to link several patterns so as to generalize the results to the whole studied area, named functional area.

A final step is needed to format the results showing anamorphosis or other outputs: smoothing vectors and smoothing maps. ${ }^{2}$ These innovative maps reveal the structure and the consequences of the network growth.

\section{A Space-Time Distortion of the French Boundaries}

These maps (Figure 6) show the results of anamorphosis with regard to the French railway network at four dates. The spatial and qualitative structure of the network had brought about an irregular distortion of the French area. Three main points are noteworthy.

Firstly, around Paris we see a contractive effect associated with the Legrand star plan. This centralizing structure carried out the political commitment to directly connect the capital to major provincial cities, frontiers, and coastal areas. Aside from the Parisian effects, we see additional spatial disparities, most notably a contracted area (in the North and East) that contrasts with the more distended Southern and Western areas. Secondly, the pattern accentuates the primacy of urban and industrial areas that specialized in mining, steel, or textile industries, and their privileged position in relation to rail transport. Conversely, rural areas with relatively weak economic power suffered on account of isolation from the rail network; the effect is particularly evident in Brittany, Provence, and mountainous areas (Massif Central, Alps, and Pyrenees). Thirdly, another effect is evident along two axes: Paris-Lyon-Marseille (PLM) and Paris-Bordeaux.
The anamorphosis here represents contractions seen between Marseille-Lyon or Toulouse-Bordeaux, and distortions due to unfavorable positions of cities like Nice or Pau that were not integrated into the rail network until comparatively late dates.

The construction of the local lines improved the quality of rail service for small cities and towns, but the disparities remained. Here it is worth noting a methodological point pertaining to the maps. Anamorphosis expresses the structure of a relative area. In our case, the spatial distortions indicate accessibility disparities. Network growth tended to diminish disparities in travel times. The map shows a gradual reduction of the gap between functional area and reference area. However, despite a gradual increase in train speed, we observe contractions around Paris and the French frontiers. For example, the opening of rail lines in Brittany and the French Riviera tended to contract these areas after 1880. In Brittany, we see North-South contraction, due to the construction of the local transversal rail lines. Despite this expansion, at the national scale the division between North and South persists but at a reduced level. Indeed, a geographic evening gradually appears across the French areas linked by the national network.

\section{A Relative Homogenization of the French Space-Time}

The evening or homogenization of accessibility across France is clearly seen during the period 1900-30; the grid distortions make it particularly apparent. The cells gradually become regular, and the large blank areas that highlight striking differences between the functional and reference maps tend to disappear. We can see certain stability of anamorphosis at this point and to a lesser degree after 1880 . We observe strong spatial growth when more than $25,000 \mathrm{~km}$ of new rail lines were added between 1880 and 1930. Because the secondary and local lines are characterized by slower speeds, they likely had a comparatively weak effect across the whole of France. Their local effects were perhaps more significant. Nevertheless, beginning in 1930 local lines are less frequently used, aggravating the financial difficulties of the main companies and leading to the nationalization of the network in 1938 under the French National Railway Company (SNCF).

Possibly, the short-lived local network did not eliminate North/South disparities. In the Northern parts of France, our maps show a reduction in differences between their functional and reference areas, yet distortions persist in the South. The economic dynamism of the North in that period contributed to development and success of the Baron Rothschild's Northern railway company, which while particularly beneficial in terms of the transport of goods, also produced benefits in terms of workforce transportation and passenger traffic. 


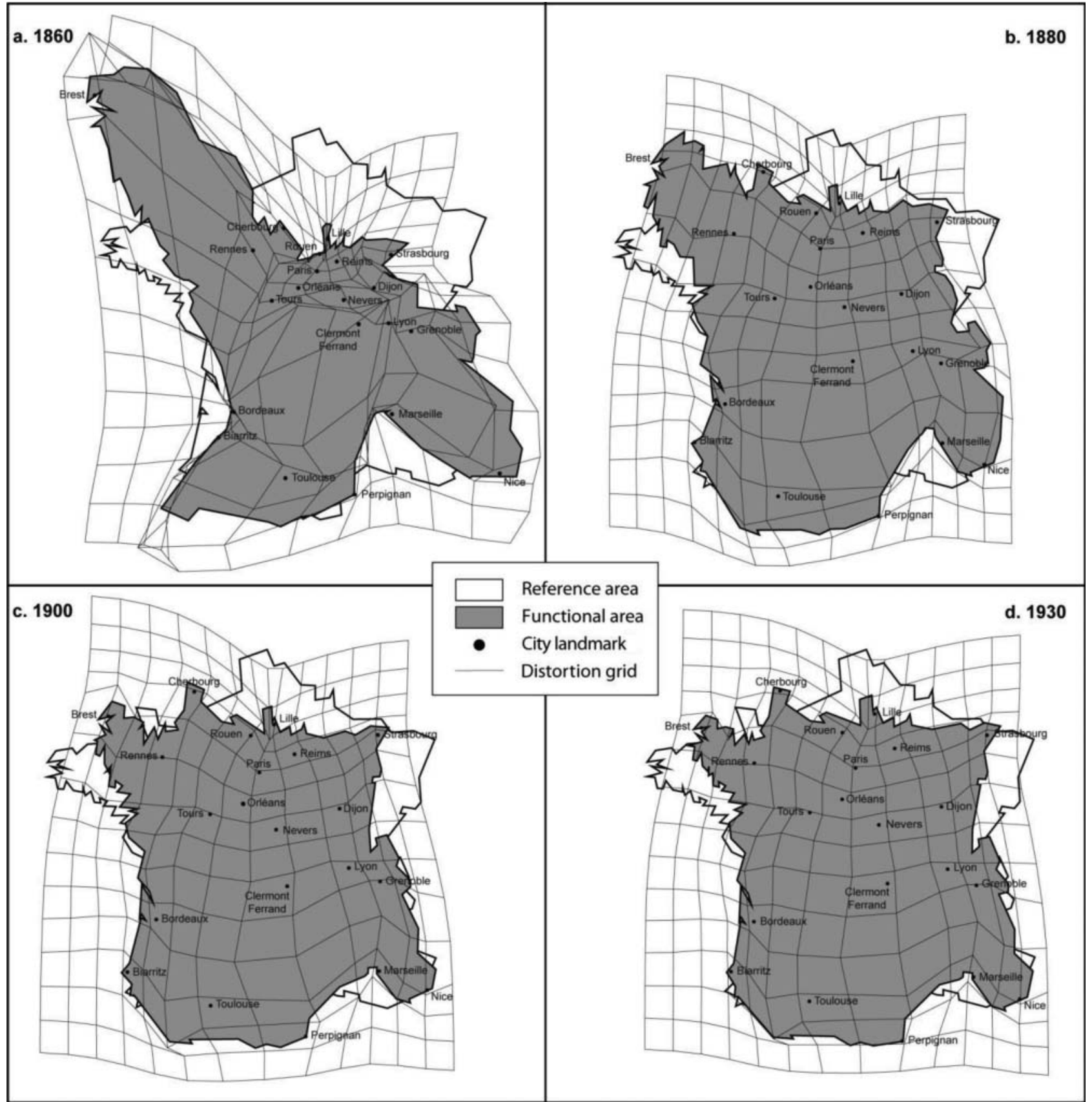

FIGURE 6. Evolution of space distortions over time.

\section{Conclusion}

Railway growth stimulated the economic dynamism of Northern France from 1830 to 1930. In the South of France, the evening effect of rail expansion was more evident in the increasing rates of agricultural productivity and growth (Schwartz et al. 2011). The Freycinet Plan of 1878 recog- nized that an extensive and efficient transportation network was essential for economic, agricultural, and demographic development. Today, many governments share that belief and thereby justify the construction of important infrastructure projects. Among the critics of these ideas are historians who use aggregate national scale data to argue that the stimulating effect of expanded transport networks is limited to 
certain kinds of areas. In the French case, the statistical unit is usually based on the administrative division of the department (Toutain 1993). This scale masks the spatial inequalities of development between and inside the department. Moreover, this spatial unit blurs the distinction between rural and urban areas. Consequently, it is difficult to understand the role of transportation infrastructures on the rural exodus and the urbanization process. The database described in this article offers new opportunities for research and improved understandings because it is multi-scalar: It permits analysis of network effects and their interactions at different geographic scales of activity (i.e., at the national, regional, and local levels) over long periods of change.

Looking to future work, there are three tasks to accomplish. First, to extend our study to periods after 1930, we must collect additional spatial and attribute data on road networks whose importance grew as the gasoline-powered transport expanded. Secondly, we must examine the multiscalar data to better assess the effects of transport networks at regional and local levels. For the urban point of view, we will provide other accessibility maps for the main French cities, Lille, Lyon, and Marseille, in order to understand the spatial inequalities from the North to the South. At the regional scale, we will observe the contrast of development between industrial (Nord Pas de Calais) and agricultural region (Midi-Pyrénée). For this purpose, we will use, for example, geographically weighted regression to describe spatially varying relationships over time (Fotheringham, Brunsdon, and Charlton 2009). This leads to the third task: comparing France with Great Britain and Spain to identify key factors that link transport with economic and population change.

\section{NOTES}

1. Anamorphic maps are like conventional maps whose surface areas and boundaries are distorted (often beyond recognition) in a way that reflects the actual, practical accessibility between all bounded areas and those that are adjacent. Areas' familiar sizes and outlines get shrunken or distended, depending on the time elapsed in moving between any two points: one of origin, one of destination.

2. The design of the following maps is based on the freeware DARCY developed by TheMA et LIV laboratories. For more information, see http://www.spatial-modelling.info/Darcy-2-module-de-comparaison.

\section{REFERENCES}

Blier, G. 1991. Nouvelle géographie ferroviaire de la France. Vol 1 : Le réseau, structure et fonctionnement. Paris: La Vie du Rail.

Boonstra, O. W. A. 2009. No place in history-Geo-ICT and historical science. GeoJournal Library 96: 87-101.

Bretagnolle, A. 2003. Vitesse des transports et sélection hiérarchique entre les villes françaises. Données Urbaines 4: 309-23.

Bretagnolle, A., and N. Verdier. 2007. L'extension du réseau des routes de poste en France, de 1708 à 1833. Postes d'Europe 18: 155-73.

Caron, F. 1997. Histoire des chemins de fer en France. Paris: Fayard.
Cauvin, C. 1998. Des transformations cartographiques. Mappemonde 49: $12-15$.

Chapelon, L., and R. Leclerc. 2007. Accessibilité ferroviaire des villes françaises en 2020. Vol. 24. Paris: CNRS-GDR Libergéo.

Cobb, M. H. 2006. The railways of Great Britain: A historical atlas at the scale of 1 inch to 1 mile. Surrey, UK: Ian Allan.

Crafts, N., T. Leunig, and A. Mulatu. 2008. Were British railway companies well managed in the early twentieth century? The Economic History Review 61(4): 842-866.

D'Arcy Thompson, W. 1917. On growth and form. New York: MacMillan, 1948.

Domengie, H. 1985. Les petits trains de jadis, Vol. 6: Sud-Est de la France. Editions du Cabri.

- 1986. Les petits trains de jadis, Vol. 7: Sud-Ouest de la France. Breil-Sur-Roya: Editions du Cabri.

Domengie, H., and J. Banaudo. 1990. Les petits trains de jadis, Vol. 8: Ouest de la France. Breil-Sur-Roya: Editions du Cabri. du Cabri.

1995a. Les petits trains de jadis, Vol. 9: Nord de la France. Editions du Cabri.

Fotheringham, A. S., C. Brunsdon, and M. E. Charlton. 2009. Geographically weighted regression. In The SAGE handbook of spatial analysis, edited by A. S. Fotheringham and P. A. Rogerson, 243. London: Sage.

Geurs, K. T., and J. R. Ritsema van Eck. 2001. Accessibility measures: Review and applications. RIVM Report 408505 006. Bilthoven: National Institute of Public Health and the Environment.

Goodchild, M. F. 2000. GIS and transportation: Status and challenges. GeoInformatica 4(2): 127-39.

Gould, S. J. 1971. D'Arcy Thompson and the science of form. New Literary History 2(2): 229-258.

Gregory, I. N., and P. S. Ell. 2007. Historical GIS: Technologies, methodologies and scholarship. Cambridge: Cambridge University Press.

Gregory, I. N., J. Marti-Henneberg, and F. J. Tapiador. 2010. Modelling long-term pan-European population change from 1870 to 2000 by using geographical information systems. Journal of the Royal Statistical Society: Series A (Statistics in Society) 173(1): 31-50.

Gregory, I. N., and R. M. Schwartz. 2009. National Historical Geographical Information System as a tool for historical research: Population and railways in Wales, 1841-1911. International Journal of Humanities and Arts Computing 3(1-2): 143-61.

Hansen, W. G. 1959. How accessibility shapes land use. Journal of the American Planning Association 25(2): 73-76.

Knowles, A. K. 2005. Emerging trends in historical GIS. Historical Geography 33:7-13.

Kwan, M. P., A. T. Murray, M. E. O'Kelly, and M. Tiefelsdorf. 2003. Recent advances in accessibility research: Representation, methodology and applications. Journal of Geographical Systems 5(1): 129-138.

Marti-Henneberg, J. 2012. European integration and national models for railway networks (1840-2010). Journal of Transport Geography 26: 126-38.

Motte, C., I. Séguy, and C. Théré. 2003. Communes d'hier, communes d'aujourd'hui: Les communes de la France métropolitaine, 1801-2001: Dictionnaire d'histoire administrative. Paris: INED.

Schwartz, R., I. Gregory, and T. Thévenin. 2011. History of railways, uneven development and population change in France and Great Britain, 1850-1914. The Journal of Interdisciplinary History 42(1): 53-88.

Studeny, C. 1995. L'invention de la vitesse: France, XVIIIe-XXe siècle. Paris: Gallimard

Thill, J. C. 200. Geographic information systems for transportation in perspective. Transportation Research Part C: Emerging Technologies 8(1-6): $3-12$.

Toutain, J.-C. 1993. La production agricole de la France de 1810 à 1990: Départements et régions: Croissance, productivité, structures. Grenoble: Presses Universitaires de Grenoble.

Vidal de la Blache, P. 1903. Tableau géographique de la France, Editions Talendier, coll. Paris: Monumenta Historiae, 1979. 